\title{
Acute myopathic quadriplegia in patients with COVID-19 in the intensive care unit
}

Francesca Madia, MD, Barbara Merico, MD, Guido Primiano, MD, PhD, Salvatore Lucio Cutuli, MD, Gennaro De Pascale, MD, and Serenella Servidei, MD

Neurology ${ }^{\circledR} 2020 ; 95: 492-494$. doi:10.1212/WNL.0000000000010280

It is well known that the spectrum of SARS-CoV-2 infection ranges from asymptomatic or mildly symptomatic patients to rapidly progressive, acute respiratory distress syndrome (ARDS) and death. Although various reports indicated the presence of myalgia in 44\%-70\% and increased creatine kinase (CK) in about $33 \%$ of hospitalized patients, ${ }^{1}$ or < skeletal muscle injury> (increased CK and myalgia) in $23 \%,{ }^{2}$ the characterization of neuromuscular involvement is still unsatisfactory, and no electrophysiologic studies have been performed. Very recently, patients who developed the Guillain-Barré syndrome (GBS) in the course of coronavirus disease 2019 (COVID-19) have been described. ${ }^{3}$ In the past literature, there were a few reports of neuromuscular involvement in association with other beta-coronavirus, including critical illness myopathy (CIM) or polyneuropathy. ${ }^{1,4}$ Moreover, myopathic changes, as fiber atrophy or necrosis, have been reported in postmortem muscle samples of 8 patients who died of SARS (severe acute respiratory syndrome) due to SARS-CoV infection. ${ }^{4}$

\section{Patients}

In the intensive care unit (ICU), we evaluated 6 ventilator-dependent SARS-CoV-2confirmed patients for acute flaccid quadriplegia, which was noticed in attempting to lighten sedation and mechanical ventilation support. The age of the patients, 5 men and 1 woman, ranged from 51 to 72 years. In all patients, neurologically normal individuals, symptoms at the onset were fever and dyspnea rapidly evolving in ARDS requiring orotracheal intubation (OTI). Other comorbidities were myelofibrosis on therapy with low dose $(12.5 \mathrm{mg}$ ) of prednisone (patient 2 ), insulin resistance (patient 4$)$, and insulindependent diabetes and blood hypertension (patient 6 ). All 6 had pneumonia with characteristic bilateral patchy ground-glass opacities and interstitial changes and various superimposed infections or sepsis. Therapies, including specific COVID-19 protocols and treatments of complications, are listed in the table. All had hydroxychloroquine and enoxaparin since the beginning of symptoms. Time from the onset of COVID-19 manifestations and OTI was 6-14 days and from OTI and electrophysiologic studies 6-14 days (table). The neurologic examination in all 6 patients showed preserved extraocular, mimic and tongue muscles, flaccid quadriplegia with possibilities of little distal movements of the hands, no sensory abnormalities, retained but weak deep tendon reflexes. Neurophysiologic studies that included EMG and motor and sensory electroneurography (ENG) demonstrated in all subjects (1) myopathic abnormalities with fibrillation potentials and rapid recruitment of small, polyphasic motor units in deltoid or biceps, quadriceps, and tibial anterior, (2) reduced compound muscle action potential amplitude (below $40 \%-80 \%$ of normal) with markedly prolonged duration (table), (3) normal sensory nerve action potential amplitudes (table), (4) normal $\mathrm{F}$ wave (table), (5) absence of demyelinating features, and (6) normal repetitive motor nerve stimulation (4/4 patients). CK, normal or mildly elevated, with the highest level of $1274 \mathrm{UI} / \mathrm{L}$ in patient 4 , decreased to normal or low-normal values in the course of the disease. All subjects had low serum proteins and elevated levels of C-reactive protein, D-dimer, and IL-6 (table). All patients were put on diet

\section{Correspondence}

Dr. Servidei

serenella.servidei@unicatt.it

\section{MORE ONLINE}

COVID-19 Resources

For the latest articles, invited commentaries, and blogs from physicians around the world NPub.org/COVID19

From the UOC Neurofisiopatologia (F.M., B.M., G.P., S.S.), Fondazione Policlinico Universitario A. Gemelli IRCCS; Dipartimento di Scienze dell'Emergenza (S.L.C., G.D.P.), Anestesiologiche e della Rianimazione, Fondazione Policlinico Universitario A. Gemelli IRCCS; and Dipartimento Universitario di Neuroscienze (S.S.), Università Cattolica del Sacro Cuore, Rome, Italy.

Go to Neurology.org/N for full disclosures. Funding information and disclosures deemed relevant by the authors, if any, are provided at the end of the article. 
Table Clinical, laboratory, and electrophysiologic findings in 6 patients with SARS-CoV-2 with flaccid quadriplegia

\begin{tabular}{|c|c|c|c|c|c|c|c|c|c|c|}
\hline Pt & Age & Sex & $\begin{array}{l}\text { Time from } \\
\text { the onset of } \\
\text { symptoms } \\
\text { to OTI/time } \\
\text { from OTI to } \\
\text { ENG/EMG }\end{array}$ & $\begin{array}{l}\text { CK } \\
\text { (UI/L) } \\
\text { max/ } \\
\text { last } \\
\text { value }\end{array}$ & $\begin{array}{l}\text { CRP } \\
\mathrm{mg} / \mathrm{L} \\
\mathrm{max} \\
\text { value }\end{array}$ & $\begin{array}{l}\text { IL-6 } \\
\text { ng/mL } \\
\text { max } \\
\text { value }\end{array}$ & $\begin{array}{l}\text { D- } \\
\text { dimer } \\
\text { ng/mL } \\
\text { max } \\
\text { value }\end{array}$ & Treatment & $\begin{array}{l}\text { Motor nerve conduction } \\
\text { studies }^{\text {a }} \\
\text { Proximal/distal } \\
\text { amplitude } \\
\text { Conduction velocity }\end{array}$ & $\begin{array}{l}\text { Antidromic } \\
\text { sensory } \\
\text { nerve } \\
\text { conduction } \\
\text { studies }^{a}\end{array}$ \\
\hline 1 & 51 & $M$ & $11 / 6 d$ & $\begin{array}{l}116 / \\
33\end{array}$ & 155.1 & 18.4 & 7,628 & $\begin{array}{l}\text { Levofloxacin, linezolid, } \\
\text { oxacillin, piperacillin/ } \\
\text { tazobactam, darunavir/ } \\
\text { ritonavir, } \\
\text { hydroxychloroquine, } \\
\text { tocilizumab, and } \\
\text { enoxaparin }\end{array}$ & $\begin{array}{l}\text { Peroneal nerve: DML } 4.7 \text { ms, } \\
\text { CMAP: } 0.4 / 0.3 \text { mV, } 40 \text { m/s, } \\
\text { mean CMAP duration } 20.2 \\
\text { ms } \\
\text { Tibial nerve: DML } 4.0 \text { ms, } \\
\text { CMAP: } 2.7 \text { mV, F wave: } 55.7 \\
\text { ms, } \\
\text { Mean CMAP duration } 18.7 \\
\text { ms }\end{array}$ & $\begin{array}{l}\text { Superficial } \\
\text { peroneal } \\
\text { nerve: SCV } \\
48 \mathrm{~m} / \mathrm{s} \text {, } \\
\text { SNAP } 3.9 \mu \mathrm{V} \text {. } \\
\text { Radial } \\
\text { nerve: SCV } \\
49 \mathrm{~m} / \mathrm{s} \text {, } \\
\text { SNAP } \\
12.3 \mu \mathrm{V}\end{array}$ \\
\hline 2 & 70 & $M$ & $6 / 9 d$ & $\begin{array}{l}500 / \\
167\end{array}$ & 363.9 & $5,402.2$ & 4,361 & $\begin{array}{l}\text { Linezolid, piperacillin/ } \\
\text { tazobactam, lopinavir/ } \\
\text { ritonavir, } \\
\text { hydroxychloroquine, } \\
\text { tocilizumab, and } \\
\text { enoxaparin }\end{array}$ & $\begin{array}{l}\text { Peroneal nerve: DML } 4.8 \\
\text { ms, CMAP: } 0.3 / 0.3 \mathrm{mV}, 40 \\
\text { m/s, } \\
\text { Mean CMAP duration } 18.3 \\
\text { ms }\end{array}$ & $N A^{b}$ \\
\hline 3 & 53 & $M$ & $12 / 8 d$ & $\begin{array}{l}1,274 / \\
89\end{array}$ & 33 & 95.6 & 5,238 & $\begin{array}{l}\text { Azithromycin, ceftriaxone, } \\
\text { levofloxacin, linezolid, } \\
\text { vancomycin, amikacin, } \\
\text { meropenem, lopinavir/ } \\
\text { ritonavir, darunavir/ } \\
\text { ritonavir, endovenous } \\
\text { corticosteroids, } \\
\text { hydroxychloroquine, } \\
\text { tocilizumab, and } \\
\text { enoxaparin }\end{array}$ & $\begin{array}{l}\text { Peroneal nerve: DML } 4.7 \text { ms, } \\
\text { CMAP: } 0.5 / 0.4 \text { mV, } 41 \text { m/s, } \\
\text { Mean CMAP duration } 14.2 \\
\text { ms } \\
\text { Tibial nerve: DML } 4.0 \text { ms, } \\
\text { CMAP: } 3.6 \text { mV, F wave: } 60 \\
\text { ms, mean CMAP duration } \\
19.1 \text { ms }\end{array}$ & $\begin{array}{l}\text { Superficial } \\
\text { peroneal } \\
\text { nerve: } \mathrm{SCV} \\
48 \mathrm{~m} / \mathrm{s} \\
\text { SNAP } 4.7 \mu \mathrm{V}\end{array}$ \\
\hline 4 & 72 & $M$ & $14 / 10 \mathrm{~d}$ & $55 / 17$ & 100.1 & 32.2 & 3,286 & $\begin{array}{l}\text { Azithromycin, doxycycline, } \\
\text { darunavir/ritonavir, } \\
\text { endovenous } \\
\text { corticosteroids, } \\
\text { hydroxychloroquine, } \\
\text { sarilumab, and } \\
\text { enoxaparin }\end{array}$ & $\begin{array}{l}\text { Tibial nerve: DML } 4.5 \text { ms, } \\
\text { CMAP: } 6.8 \mathrm{mV} \text {, F wave: } 54.4 \\
\text { ms. mean CMAP duration } \\
20.2 \text { ms. Ulnar nerve: } \mathrm{DML} \\
2.9 \mathrm{~ms} \text {, CMAP: } 1.9 / 1.5 \mathrm{mV} \text {, } \\
49 \mathrm{~m} / \mathrm{s} \text {; mean CMAP } \\
\text { duration } 14.2 \mathrm{~ms}\end{array}$ & $\begin{array}{l}\text { Ulnar nerve: } \\
\text { SCV } 50 \mathrm{~m} / \mathrm{s} \\
\text { SNAP } 1.9 \mu \mathrm{V}\end{array}$ \\
\hline 5 & 52 & $M$ & $14 / 10 \mathrm{~d}$ & $\begin{array}{l}133 / \\
111\end{array}$ & 256.1 & 82.9 & 6,408 & $\begin{array}{l}\text { Linezolid, imipenem, } \\
\text { amoxicillin, darunavir/ } \\
\text { ritonavir, endovenous } \\
\text { corticosteroids, } \\
\text { hydroxychloroquine, } \\
\text { tocilizumab, and } \\
\text { enoxaparin }\end{array}$ & $\begin{array}{l}\text { Median nerve: DML } 3.1 \mathrm{~ms} \text {, } \\
\text { CMAP: } 3.7 / 3.5 \mathrm{mV}, 46 \mathrm{~m} / \mathrm{s} \\
\text { F wave: } 28.9 \mathrm{~ms} \text {, mean } \\
\text { CMAP duration } 14.9 \mathrm{~ms}\end{array}$ & $\begin{array}{l}\text { Median } \\
\text { nerve: SCV } \\
59 \mathrm{~m} / \mathrm{s} \\
\text { SNAP } \\
11.9 \mu \mathrm{V}\end{array}$ \\
\hline 6 & 68 & $\mathrm{~F}$ & $7 / 14 d$ & $\begin{array}{l}203 / \\
70\end{array}$ & 196.8 & 123.9 & 2076 & $\begin{array}{l}\text { Azithromycin, ceftriaxone, } \\
\text { darunavir/ritonavir, } \\
\text { hydroxychloroquine, } \\
\text { sarilumab, and } \\
\text { enoxaparin }\end{array}$ & $\begin{array}{l}\text { Median nerve: DML } 4.2 \mathrm{~ms} \text {, } \\
\text { CMAP: } 3.8 / 3.7 \mathrm{mV}, 45 \mathrm{~m} / \mathrm{s} \\
\text { F wave: } 28.8, \text { mean CMAP } \\
\text { duration } 18.1 \mathrm{~ms}\end{array}$ & $\begin{array}{l}\text { Radial } \\
\text { nerve: SCV } \\
47 \mathrm{~m} / \mathrm{s} \\
\text { SNAP } 6.3 \mu \mathrm{V}\end{array}$ \\
\hline
\end{tabular}

Abbreviations: $C K=$ creatine kinase; $C M A P=$ compound muscle action potential; $C R P P=C$-reactive protein; $\mathrm{DML}=$ distal $\mathrm{motor}$ latency; $\mathrm{ENG}=$ electroneurography; F wave = mean F-wave latency; Max = maximum; MCV = motor conduction velocity; $\mathrm{NA}=$ not available. $\mathrm{OTI}=$ orotracheal intubation; $\mathrm{Pt}=$ patient; $\mathrm{SCV}=$ sensory conduction velocity; SNAP = sensory nerve action potential.

Normal nerve conduction study values in our laboratory: median nerve, CMAP $\geq 4-5 \mathrm{mV}, \mathrm{DML} \leq 4 \mathrm{~ms}$, and MCV $\geq 45 \mathrm{~m} / \mathrm{s}$; ulnar nerve, CMAP $\geq 6 \mathrm{mV}, \mathrm{DML}<3 \mathrm{~ms}$, and $\mathrm{MCV} \geq 46 \mathrm{~m} / \mathrm{s}$; tibial nerve, CMAP $\geq 5 \mathrm{mV}$ and $\mathrm{DML} \leq 5 \mathrm{~ms}$; peroneal nerve, $\mathrm{CMAP} \geq 2 \mathrm{mV}$, DML $\leq 5 \mathrm{~ms}$, and $\mathrm{MCV}>39 \mathrm{~m} / \mathrm{s}$; radial nerve, $\mathrm{SNAP} \geq 5 \mu \mathrm{V}$ and $\mathrm{SCV}$ $\geq 45 \mathrm{~m} / \mathrm{s}$; superficial peroneal nerve, SNAP $\geq 5 \mu \mathrm{V}$ and SCV $\geq 40 \mathrm{~m} / \mathrm{s}$; nerve F-wave cutoff was corrected for the height: $\mathrm{median}$ nerve, $150 \mathrm{~cm} \leq 25 \mathrm{~ms}, 160 \mathrm{~cm} \leq 27$ $\mathrm{ms}, 170 \mathrm{~cm} \leq 29 \mathrm{~ms}, 180 \mathrm{~cm} \leq 30 \mathrm{~ms}$, and $190 \mathrm{~cm} \leq 31 \mathrm{~ms}$; tibial nerve, $150 \mathrm{~cm} \leq 44 \mathrm{~ms}, 160 \mathrm{~cm} \leq 48 \mathrm{~ms}, 170 \mathrm{~cm} \leq 53 \mathrm{~ms}, 180 \mathrm{~cm} \leq 58 \mathrm{~ms}$, and $190 \mathrm{~cm} \leq 60 \mathrm{~ms}$. Mean age of controls was $52 \pm 18$ years (range 8-94 years). Control mean CMAP duration: peroneal nerve 5.5 ms, tibial nerve 5.4 ms, median nerve 5.4 ms, and ulnar nerve $6.0 \mathrm{~ms}$.

Normal laboratory values: CK 30-170 UI/L, CRP $<5$ mg/L, IL-6 <4.4 ng/mL, and D-dimer $<500$ ng/mL.

a The neurophysiologic protocol variability is due to the clinical condition (i.e., edema and venous/arterial access).

${ }^{b}$ Due to environmental artifacts.

with high content of proteins and vitamins. Patient 2, with the highest value of IL-6 $(5,402 \mathrm{ng} / \mathrm{mL})$, died shortly after of intractable sepsis. Neurologic examination in the other 5 patients, 14 to 20 days from the first examination, showed a clear improvement of muscular deficit. All of them are disconnected from the ventilator and capable to move and use their hands; $4 / 5$ patients were able to sit unaided, and 1 was able to stand with aid. 


\section{Discussion}

Differential diagnosis of flaccid quadriplegia includes GBS, critical illness neuropathy and/or myopathy, and toxic myopathy. However, on the bases of EMG/ENG studies, clinical features with preserved face expression and ocular movements and the favorable outcome of muscle weakness, a diagnosis of CIM appears the most likely. Moreover, CIM major risk factors are severe respiratory distress, systemic inflammatory response, sepsis, hyperglycemia, steroids, and neuromuscular blockade, ${ }^{5}$ factors that are mostly present in these patients. Although episodes of rhabdomyolysis have been reported during treatment with lopinavir/ritonavir in combination with a statin in HIV, ${ }^{1}$ a toxic myopathy is instead unlike as none of our patients were taking statins, and there was no evidence of acute myonecrosis with $\mathrm{CK}$, which decreased in a few days.

By contrast, a direct effect of the virus on the muscle cannot be excluded. The mechanism of spreading, similarly to SARS$\mathrm{CoV}$, probably relies in SARS-CoV-2 ability to enter into the cells that express the angiotensin-converting enzyme 2 (ACE2) receptors. ${ }^{6}$ Of interest, ACE2 is expressed in muscle and involved in the pathways implicated on insulin resistance, myoatrophy, and fibrosis. ${ }^{7}$ Although SARS-CoV has not been found in the postmortem skeletal muscles showing features compatible with CIM from 2 patients who died of SARS, SARS-CoV-2 seems to have much higher affinity to ACE2 than SARS-CoV, and a direct insult of the virus cannot be ruled out. Alternatively, muscle involvement could be the result of immune-mediated damage in the contest of the hyperinflammation typical of the more advanced phases of COVID-19.

Whatever the mechanism, muscle weakness may contribute to prolonged mechanical ventilation and ventilator wean failure. $\mathrm{CIM}$ is a relatively frequent complication in ICU $5^{5}$ maybe still under recognized in the setting of patients with COVID-19 for the overwhelming severe systemic manifestations and mortality. This is just a tile in the complex clinical pictures of SARS-CoV-2 infection but warrants further and more systemic studies to ensure the best possible approach to these patients.

\section{Acknowledgment}

The authors thank all the doctors and nurses involved in the care of these patients.
Study funding

No targeted funding reported.

\section{Disclosure}

The authors report no disclosures relevant to the manuscript. Go to Neurology.org/N for full disclosures.

\section{Publication history}

Received by Neurology May 5, 2020. Accepted in final form June 22, 2020.

Appendix Authors

\begin{tabular}{|c|c|c|}
\hline Name & Location & Contribution \\
\hline $\begin{array}{l}\text { Francesca } \\
\text { Madia, MD }\end{array}$ & $\begin{array}{l}\text { Fondazione Policlinico } \\
\text { Universitario A. Gemelli } \\
\text { IRCCS, Rome, Italy }\end{array}$ & $\begin{array}{l}\text { Designed and } \\
\text { conceptualized the study } \\
\text { and analyzed the data }\end{array}$ \\
\hline $\begin{array}{l}\text { Barbara } \\
\text { Merico, MD }\end{array}$ & $\begin{array}{l}\text { Fondazione Policlinico } \\
\text { Universitario A. Gemelli } \\
\text { IRCCS, Rome, Italy }\end{array}$ & $\begin{array}{l}\text { Major role in the } \\
\text { acquisition of data and } \\
\text { revised the manuscript for } \\
\text { intellectual content }\end{array}$ \\
\hline $\begin{array}{l}\text { Guido } \\
\text { Primiano, } \\
\text { MD, PhD }\end{array}$ & $\begin{array}{l}\text { Fondazione Policlinico } \\
\text { Universitario A. Gemelli } \\
\text { IRCCS, Rome, Italy }\end{array}$ & $\begin{array}{l}\text { Major role in the } \\
\text { acquisition of data and } \\
\text { revised the manuscript for } \\
\text { intellectual content }\end{array}$ \\
\hline $\begin{array}{l}\text { Salvatore } \\
\text { Lucio } \\
\text { Cutuli, MD }\end{array}$ & $\begin{array}{l}\text { Fondazione Policlinico } \\
\text { Universitario A. Gemelli } \\
\text { IRCCS, Rome, Italy }\end{array}$ & $\begin{array}{l}\text { Major role in the } \\
\text { acquisition of data }\end{array}$ \\
\hline $\begin{array}{l}\text { Gennaro } \\
\text { De Pascale, } \\
\text { MD }\end{array}$ & $\begin{array}{l}\text { Fondazione Policlinico } \\
\text { Universitario A. Gemelli } \\
\text { IRCCS, Rome, Italy }\end{array}$ & $\begin{array}{l}\text { Major role in the } \\
\text { acquisition of data }\end{array}$ \\
\hline $\begin{array}{l}\text { Serenella } \\
\text { Servidei, } \\
\text { MD }\end{array}$ & $\begin{array}{l}\text { Fondazione Policlinico } \\
\text { Universitario A. Gemelli } \\
\text { IRCCS, Rome, Italy }\end{array}$ & $\begin{array}{l}\text { Designed and } \\
\text { conceptualized the study; } \\
\text { analyzed the data; revised } \\
\text { the manuscript for } \\
\text { intellectual content; and } \\
\text { drafted the manuscript }\end{array}$ \\
\hline
\end{tabular}

\section{References}

1. Guidon AC, Amato AA. COVID-19 and neuromuscular disorders. Neurology 2020 94:959-969.

2. Mao L, Jin H, Wang M, et al. Neurologic manifestations of hospitalized patients with coronavirus disease 2019 in Wuhan, China. JAMA Neurol 2020;77:683-690.

3. Toscano G, Palmerini F, Ravaglia S, et al. Guillain-barré syndrome associated with SARS-CoV-2. N Engl J Med 2020;382:2574-2576.

4. Leung TW, Wong KS, Hui AC, et al. Myopathic changes associated with severe acute respiratory syndrome: a postmortem case series. Arch Neurol 2005;62:1113-1117.

5. Shepherd S, Batra A, Lerner DP. Review of critical illness myopathy and neuropathy. Neurohospitalist 2017;7:41-48.

6. Yan T, Xiao R, Lin G. Angiotensin-converting enzyme 2 in severe acute respiratory syndrome coronavirus and SARS-CoV-2: a double-edged sword? FASEB J 2020;34:6017-6026.

7. Cabello-Verrugio C, Morales MG, Rivera JC, Cabrera D, Simon F. Renin-angiotensin system: an old player with novel functions in skeletal muscle. Med Res Rev 2015;35:437-463. 


\section{Neurology}

Acute myopathic quadriplegia in patients with COVID-19 in the intensive care unit Francesca Madia, Barbara Merico, Guido Primiano, et al.

Neurology 2020;95;492-494 Published Online before print June 29, 2020

DOI 10.1212/WNL.0000000000010280

This information is current as of June 29, 2020

$\begin{array}{ll}\begin{array}{l}\text { Updated Information \& } \\ \text { Services }\end{array} & \begin{array}{l}\text { including high resolution figures, can be found at: } \\ \text { http://n.neurology.org/content/95/11/492.full }\end{array} \\ \text { References } & \text { This article cites } 7 \text { articles, } 1 \text { of which you can access for free at: } \\ \text { http://n.neurology.org/content/95/11/492.full\#ref-list-1 } & \text { This article, along with others on similar topics, appears in the } \\ \text { following collection(s): } \\ \text { Critical care } \\ \text { http://n.neurology.org/cgi/collection/critical_care } \\ \text { EMG } \\ \text { http://n.neurology.org/cgi/collection/emg } \\ \text { Muscle disease } \\ \text { http://n.neurology.org/cgi/collection/muscle_disease } \\ \text { Information about reproducing this article in parts (figures,tables) or in } \\ \text { its entirety can be found online at: } \\ \text { http://www.neurology.org/about/about_the_journal\#permissions } \\ \text { Information about ordering reprints can be found online: } \\ \text { http://n.neurology.org/subscribers/advertise }\end{array}$

Neurology ${ }^{\circledR}$ is the official journal of the American Academy of Neurology. Published continuously since 1951 , it is now a weekly with 48 issues per year. Copyright (C) 2020 American Academy of Neurology. All rights reserved. Print ISSN: 0028-3878. Online ISSN: 1526-632X.

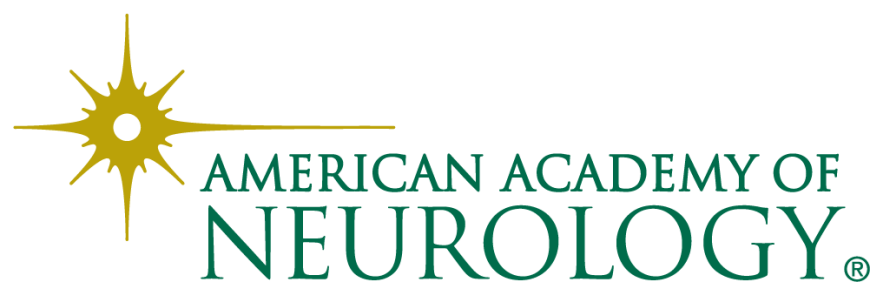

